\title{
THE CORRELATION BETWEEN STUDENTS' INTEREST AND THEIR READING COMPREHENSION LEVEL IN SHORT PASSAGES
}

\author{
Jihan Alfaizah \\ Universitas Islam Negeri Alauddin Makassar \\ jihanalfaizah23@gmail.com \\ Wahyuddin Naro \\ Universitas Islam Negeri Alauddin Makassar \\ wahyuddin.naro@yahoo.co.id \\ Kamsinah \\ Universitas Islam Negeri Alauddin Makassar \\ kamsinah@uin-alauddin.ac.id
}

Doi: $10.24252 /$ elties.v\%vi\%i.12663

\begin{abstract}
The study aims at finding out the relationship between students' interest and their reading comprehension level in short passages. This study was conducted at the second grade of Senior High School 10 of Gowa. The population of this study was all of the students in academic year 2019/2020 which consisted 265 students, and the sample was 30 students selected by using purposive method. The researcher applied correlational design. The researcher used the instrument to obtain the data, they were questionnaire and test. The scores from both instruments were calculated and analyzed by using statistical procedure of Product Moment Correlation to find out whether there was a correlation between the two variables or not. The result showed that there was low correlation with the index value of correlation coefficient (rxy) of 0.28 . Furthermore, the hypothesis testing showed that the index value of correlation coefficient (rxy) of 0,28 was lower than the index value of correlation coefficient of the Product Moment table (rt) of 0,306 which meant that, the null hypothesis (H0) was accepted and alternative hypothesis (H1) was rejected. Therefore, students' interest in short reading comprehension passages is in average level because only a few students are interested in English lesson especially those who have high interest and many vocabularies to learn English. Short Passages did not give a big impact on students' interest and their achievement in reading comprehension because of some factors. There is not self-interest in reading, lack of vocabulary and support parents and all of school elements in order to improve the students' reading interest optimally. The findings of this study might be used as the input for both teachers and students to improve students' reading comprehension level.
\end{abstract}

Keywords: Students' interest, achievement, reading comprehension, short passages

\section{INTRODUCTION}

Reading is one of language skills that plays important roles in many aspects of life since when people reading a text and understanding the content of the text, they can get information and share the information to other people. Reading a lot of sources can definitely enrich knowledge and passages from the texts. Furthermore, a big number of literature are still written 
in English so that reading skill is very important and it is also required in comprehending the texts.

Reading is not only important for those who are studying in school or college, but several people who are not studying there anymore since reading is one of alternative to get several information in modern area, for instance people can read some sources from books, journals, articles, magazines and newspaper. Reading requires the comprehension of what is written in the text as a process to gain information. So, mastering reading skill is a must for all people, especially for students who are studying English as a foreign language. For the students who want to develop and to extend their knowledge reading comprehension is a fundamental skill in obtaining progress, they can extend their reading knowledge by reading and comprehending books, the students are hoped to be able not only in pronouncing the words but also goal in grasping. Furthermore, it can make students success of their study depending on their greatest part of reading ability. Reading is needed by the students to get information and knowledge.

In fact, the interest is one of factor in reading activity since when the students have lack of interest to read a text, it can be requirement for students to read and they are difficult to understand the content of the text. An interest of people is one of a push from their self to read a text and get information from it. Kool (2007) stated that reading interest is defined as reading done when students are outside the school compound. Furthermore, reading interest as whether or not students like to read in their spare time or at home or whether they like to go to library. Besides, reading interest is also defined by the number of books read in a month and the number of times students read in a week and the favorite genres types of English reading materials. It is believed that students read not because they want to read, but because they have to read. Students perceive reading as a task that they have to undertake in order to excel academically.

The previous researches revealed that interest, achievement and reading comprehension have a relationship. Susanto (2006) found the correlation between students' interest and students' reading comprehension. Furthermore, Adiarti (2018) found the correlation between students' reading interest and students' reading comprehension ability. Besides, Astomo (2017) found positive correlation between students' interest of reading on english text and translation ability toward reading comprehension.

The similarity of this reseacrh with the first reserach is that both of researches have the same variable. However, these two researches have difference in the research scope. Relating some of researches above students' interest is very important in learning English especially in reading English text because, the students more prefer if the text given by the teacher is in 
accordance with the students' willingness to read in general such as a fiction book and teachers' style also influence toward students' interest in learning English. When student has an interest in reading then they can understand the content of the text along students' achievement on reading also achieved.

Based on the explanation above, it is still quite important to investigate more about the correlation between students' interests and their reading comprehension level since reading is very important for students to achieve their knowledge. The findings of this study might be used as the input for teachers and students to improve students' reading comprehension level.

\section{METHOD}

This research used a Correlational research design. Correlational research involves collecting data to determine whether, and to what degree, a relationship exists (Gay, L. R., 2006: 191). The design is as follows:

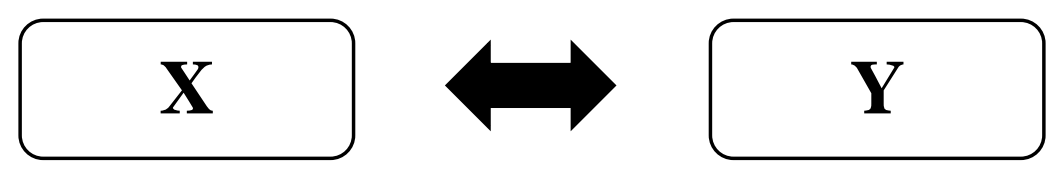

Figure 1. Correlational Research Design

A correlation study (Minium, 1993:143) is to define a relationship between two variables they are: students' interest and students' achievement in short reading comprehension passages.

The population of this research was the second year at Senior High School 10 of Gowa which consists of nine classes with 265 students. The sample of this study was selected using purposive sampling method, especially for students have lack of interest in reading text English. The researcher chose XI MIA 3 and XI MIA 4, there are 30 students and this class is recommendantion from English teacher because XI MIA 3 and XI MIA 4 had lack interest in reading text especially in English subject.

The researcher used the instrument in collecting data, they were the questionnaire and the reading test. The questionnaire consists of 40 statements in which 32 items were positive statement and the other 8 items were negative statements. Eeach item has five options with the scale of scoring from 1 to 5 if the statement negative, and the scale of scoring from 5 to 1 if the statement positive. Reading test is in the form of multiple choices with 9 text of descriptive 
text and total 40 questions to know their achievement in short reading text and to measure the level of reading comprehension of student.

\section{FINDINGS AND DISCUSSION}

1. The Classification of Students' Interest in Short Passages at the second grade of MIA 3 and MIA 4 in Senior High School 10 of Gowa.

\section{Table 1}

The Distribution of Frequency and Percentage of Students' Interest in Short Passages XI MIA 3 and MIA 4

\begin{tabular}{|l|l|c|c|c|}
\hline NO & Classification & Score & F & P(\%) \\
\hline 1. & High & $150-200$ & 4 & $13 \%$ \\
\hline 2. & Average & $99-149$ & 26 & $87 \%$ \\
\hline 3. & Low & $48-98$ & 0 & $0 \%$ \\
\hline & \multicolumn{2}{r}{ Total } & $\mathbf{2 5}$ & $\mathbf{1 0 0 \%}$ \\
\hline
\end{tabular}

The table above shows that the rate percentage of the second grade of MIA 3 and MIA 4in the quetionnare from 30 students of two classes. In addition, the highest score of students' interest was 165 and the lowest score was 120. From 30 students, there were 4 students got highest score and there were 26 students got lowest score as well. Based on the table above, the students' score got in average classification, because most of them answer the questionnare based on their experience since they learned English lesson in their class.

Table 2

The Distribution of Frequency and Percentage of XI MIA 3 and MIA 4

\begin{tabular}{|l|l|c|c|c|}
\hline NO & \multicolumn{1}{|c|}{ Classification } & Score & $\mathbf{F}$ & $\mathbf{P}(\boldsymbol{\%})$ \\
\hline 1. & Excellent & $80-100$ & 17 & $57 \%$ \\
\hline 2. & Good & $60-79$ & 13 & $43 \%$ \\
\hline 3. & Fairly Good & $40-59$ & 0 & $0 \%$ \\
\hline
\end{tabular}




\begin{tabular}{|l|l|c|c|c|}
\hline 4. & Fair & $20-39$ & 0 & $0 \%$ \\
\hline 5. & Very Poor & $0-19$ & 0 & $0 \%$ \\
\hline & \multicolumn{2}{|c|}{ Total } & $\mathbf{3 0}$ & $\mathbf{1 0 0 \%}$ \\
\hline
\end{tabular}

The table above shows that the rate percentage of the second grade MIA 3 and MIA 4in the reading test from 30 students is on excellent level because most of the student's score in the two classes are identify fair to fairly good. The findings indicate that the total score of students achievement is 2380 . The highest score was 90 and lowest score was 68 . After the researcher tested both classes using a reading test the score of the two classes are not significantly difference of 30 students.

Table 3

The Mean Score and Standard Deviation of the second grade MIA 3 and MIA 4 in Test and Questionnare

\begin{tabular}{|l|c|c|c|}
\hline \multirow{2}{*}{ Instrument } & Mean score & Standard Deviation & N \\
\hline Test & 79.3 & $\mathbf{8 0 . 9 3}$ & 30 \\
\hline Questionnare & 137.2 & 10.96 & 30 \\
\hline
\end{tabular}

\section{Hyphotesis Testing}

To test the hypotheses, the correlation coefficient $\left(\mathrm{r}_{\mathrm{xy}}\right)$ were compared to Product Moment table $\left(r_{t}\right)$. Ho or the null hypothesis will be accepted if $r_{x y} \leq r_{t}$ and rejected if $r_{x y} \geq r_{t}$. To find $\mathrm{r}$, the degrees of freedom must be determined first:

$$
\begin{gathered}
\mathrm{df}=\mathrm{N}-\mathrm{nr} \\
\mathrm{df}=30-2 \\
\mathrm{df}=28
\end{gathered}
$$

After looking at the pearson product moment table, the rt of a one-tailed test in the level of significance of $5 \%$ and $\mathrm{df}_{\mathrm{f}}$ of 28 was found to be $\mathbf{0 . 3 0 6}$. The index value of $\mathrm{r}_{\mathrm{xy}}(\mathbf{0 . 2 8})$ is lower than the index value of $\mathrm{rt}_{\mathrm{t}}(\mathbf{0 . 3 0 6})$ which meant that the alternative hypothesis was rejected and null hypothesis was accepted.

Based on the table of interpretation of correlation that, the formula of Pearson Product Moment was 0.28 . After it was consulted to the interpretation of correlation, the score was in 
interval 0.20 up to 0.40 . It means that the significance correlation of this research is low or can be told there is week correlation between those variables.

The aim of this research was to know the correlation between students' interest and their reading comprehension level in short passages at senior high school 10 of Gowa. The reseacrher found a low correlation between two variables based on the table interpration of correlation a one-tailed test in the level of significance of $5 \%$.

Some possible explanations can be given to describe a low correlation between students' interest and their reading comprehension achievement in short passages there were several factors which can influence students' interest in reading. Involve there is not selfinterest in reading, lack of vocabulary, the content of a text is not familiar, the teacher of English lesson, the bad situation of the class or library in their school, there were not a motivation and support from parents and all of school elements in order to improve the students' reading interest optimally.

Interest is one of factors that can influence students' achievement in reading comprehension but there are other factors as well. This finding goes in line with Kahayanto (2005:13) that there are two factors that influence the students' reading comprehension in achievement, they are internal factor and external factor. The internal factor is the factor which come from the reader himself or usually known as personal factor, because the factor has existed inside the reader. This factor dealt with interest and self-motivation. External factor is factor which source from reading material and teacher of reading. The students will get high score if they have interest of reading on English text is high and all those factors are more attended. Moreover, the students will get low score if they have interest on reading on English text is lack. In addition, the result of present study supports Fauziati's findings (2010:32) that reading is one of the language skills which needed be taught in language classroom. It enables us to gain new knowledge, enjoy literature, and do everyday things that are parts of modern life, such as, reading the newspapers, job listing, instruction manuals, maps and etc. It means that the more the student reads, the more knowledge they will get.

\section{CONCLUSION}

It can be concluded that students' interest in short passages does not give a big impact on students' interest and also for students' achievement in reading comprehension because some factors. There were lack of vocabulary, the content of the text is not familiar for students, the teacher of English lesson, the condition of their class was not satisfy, and there is lack interest for reading English text. Besides, students' reading comprehension achievement, 
especially at the second grade of Senior High School 10 of Gowa, was in average level since only a few students are interested in English lesson, especially for students that have high interest and many vocabularies to learn English. The findings of this study might be used as the input for teachers and students to improve students' reading comprehension level.

\section{REFERENCES}

Akanda et al. Environmental Factors Influencing Epidemic Cholera. Department of Civil and Environmental Engineering:WestVirginia UniversityMorgantownWVUSA. 2013.

AlHameed Al Odwan, TalalAbd. The Effect of the Directed Reading Thinking Activity through Cooperative Learning on English Secondary Stage Students. Reading Comprehension in Jordan, International Journal of Humanities and Social Science, Vol.2 (16), 138151. 2012.

Arikunto, Suharsimi. Prosedur Penelitian: Suatu Pendekatan Praktik. Jakarta: Rineka Cipta. 2013.

Arikunto. Metode Penelitian Kualitatif. Jakarta: Bumi Aksara. 2006.

Arikunto, Suharsimi. Prosedur Penelitian: Suatu Pendekatan Praktik. Jakarta: Rineka Cipta. 2013.

Arikunto. Metode Penelitian Kualitatif. Jakarta: Bumi Aksara. 2006.

Astomo, Dian Probo. A correlation Study between Students' Interest of Reading Comprehension Abilities. IAIN Surakarta. 2017.

Dhamarullah, Imam Achmad. The Relationship Between Movie Watching Activity and Listening Skill. Thesis. Jakarta: Faculty of Tarbiyah and Teachers' Training UIN Syarif Hidayatullah. 2015.

Fauzi, Yogi. A Correlation Study Between Students' Interest on English Text and Vocabulary Mastery toward Reading Comprehensionon Descritive Textat The Eighth Grade Students Of MTSN Ngemplak In The Academic Year Of 2016/2017. Thesis: State Islamic Institute of Surakarta. 2017.

Fauziati, E.Teaching of English as a Foreign Language. Surakarta: MuhammadiyahUniversity Press.(p.139-142). 2002.

Gay, L. R., et al.Educational Research. Columbus: Pearson Merril Prentice Hall. 2006.

Hudaibiah. The Correlation Between Students' Interest and Their Achievement in Learning English at The Second Year of SLTPN 1 Pamulang. Thesis. 2009.

McKool, S. Factors that influence the decision to read: An investigation offifth grade students' out-of-school reading habits. Reading Improvement, 44(3), 111-132. 2007. 
Nurhana. Factors Affecting Students Achievement inReading Comprehension (A Study At The Third Years Students Of SmpNegeri I BontorambaKabupatenJeneponto). 2007.

Sugiyono. MetodePenelitianPendidikan. Bandung: Alfabeta. 2016.

Susanto, Ewo Priyo, et.al. The Correlation between Students' Reading Interest and Students' Reading Comprehension. UNILA Journal of English Teaching. 2006.

Widia, Amirah Adiarti. The Correlation Between Students' Reading Interest And Students' Reading Comprehension Ability At The First Semester Of The Eleventh Grade of SMA YP Unila Bandarlampung In Academic Year Of 2018/2019. UIN Raden Intanlampung. 2018.

Acknowledgement

The researcher would like to appreciate the great thankfulness to the students of the Second Grade of Senior High School 10 of Gowa especially to XI MIA and XI MIA 4 who has been samples of this research. 